Supplement of Biogeosciences, 16, 2771-2793, 2019

https://doi.org/10.5194/bg-16-2771-2019-supplement

(C) Author(s) 2019. This work is distributed under

the Creative Commons Attribution 4.0 License.

(c) (1)

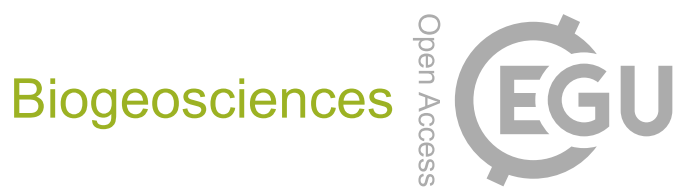

Supplement of

\title{
Decadal fates and impacts of nitrogen additions on temperate forest carbon storage: a data-model comparison
}

Susan J. Cheng et al.

Correspondence to: Susan J. Cheng (sjc265@ cornell.edu)

The copyright of individual parts of the supplement might differ from the CC BY 4.0 License. 


\section{Supplementary Information}

Table S1: Published ${ }^{15} \mathrm{~N}$ recovery measurements (\%) and CLM5-simulated $\mathrm{N}$ recoveries (\%) for each site and experiment, including for both open (Open CLM) and closed (Closed CLM) N cycle configurations. A .csv file with data from this table is available at https://doi.org/10.5281/zenodo.2772160.

\begin{tabular}{|c|c|c|c|c|c|c|c|c|c|c|c|c|c|c|c|}
\hline Site & $\begin{array}{c}\text { Years Since } \\
\text { Tracer } \\
\text { Application } \\
\end{array}$ & Foliage & Wood & Bark & $\begin{array}{l}\text { Fine } \\
\text { Roots }\end{array}$ & $\begin{array}{l}\text { Coarse } \\
\text { Roots }\end{array}$ & $\begin{array}{l}\text { Ground } \\
\text { Plants }\end{array}$ & $\begin{array}{l}\text { Organic } \\
\text { Soil }\end{array}$ & $\begin{array}{c}\text { Mineral } \\
\text { Soil }\end{array}$ & $\begin{array}{l}\text { Total } \\
\text { Plant* }\end{array}$ & $\begin{array}{c}\text { Total } \\
\text { Soil }\end{array}$ & $\begin{array}{l}\text { Open } \\
\text { CLM } \\
\text { Plant } \\
\end{array}$ & $\begin{array}{c}\text { Closed } \\
\text { CLM } \\
\text { Plant } \\
\end{array}$ & $\begin{array}{c}\text { Open } \\
\text { CLM } \\
\text { Soil } \\
\end{array}$ & $\begin{array}{c}\text { Closed } \\
\text { CLM } \\
\text { Soil } \\
\end{array}$ \\
\hline \multirow{2}{*}{$\operatorname{Arnot}^{\mathrm{a}, \mathrm{b}}$} & 1 & 1.9 & 0.6 & 1.0 & 2.5 & 4.9 & NA & 13.7 & 45.3 & 10.9 & 59.0 & 50 & 65 & 26 & 33 \\
\hline & 6 & 1.6 & 1.5 & 1.2 & 1.8 & 2.1 & NA & 5.9 & 56.5 & 8.2 & 62.4 & 16 & 24 & 63 & 73 \\
\hline \multirow{3}{*}{$\begin{array}{l}\text { Harvard } \\
\text { BDT }^{c, d, e}\end{array}$} & 1 & 1.2 & 0.6 & 0.5 & 4.6 & NA & NA & 81.9 & 11.1 & 6.8 & 92.9 & 47 & 63 & 25 & 32 \\
\hline & 8 & 3.8 & 2.1 & 1.7 & 4.2 & NA & NA & 73.9 & 15.7 & 11.8 & 89.6 & 14 & 23 & 56 & 71 \\
\hline & 17 & \multicolumn{10}{|c|}{ available upon request to site PI } & 14 & 20 & 48 & 72 \\
\hline \multirow{3}{*}{$\begin{array}{l}\text { Harvard BDT } \\
\text { Fertilized }^{\mathrm{c}, \mathrm{d}, \mathrm{e}}\end{array}$} & 1 & 5.9 & 2.9 & 1.6 & 13.7 & NA & NA & 44.6 & 27.4 & 24.0 & 72.0 & 31 & 29 & 26 & 31 \\
\hline & 8 & 3.1 & 3.1 & 2.2 & 3.1 & NA & NA & 55.4 & 16.0 & 11.5 & 71.4 & 21 & 20 & 34 & 35 \\
\hline & 17 & \multicolumn{10}{|c|}{ available upon request to site PI } & 14 & 15 & 33 & 34 \\
\hline \multirow{3}{*}{$\begin{array}{l}\text { Harvard } \\
\text { NET }^{\mathrm{c}, \mathrm{d}, \mathrm{e}}\end{array}$} & 1 & 1.0 & 0.1 & 0.2 & 2.3 & NA & NA & 60.0 & 8.8 & 3.6 & 68.7 & 38 & 49 & 51 & 49 \\
\hline & 8 & 2.9 & 1.3 & 0.6 & 3.4 & NA & NA & 56.2 & 31.9 & 8.1 & 88.1 & 24 & 24 & 58 & 72 \\
\hline & 17 & \multicolumn{10}{|c|}{ available upon request to site PI } & 18 & 16 & 60 & 78 \\
\hline \multirow{3}{*}{$\begin{array}{l}\text { Harvard NET } \\
\text { Fertilized }^{\mathrm{c}, \mathrm{d}, \mathrm{e}}\end{array}$} & 1 & 9.6 & 0.4 & 0.9 & 8.7 & NA & NA & 33.9 & 15.2 & 19.7 & 49.1 & 29 & 36 & 26 & 40 \\
\hline & 8 & 6.1 & 1.1 & 0.9 & 5.1 & NA & NA & 34.9 & 24.3 & 13.2 & 59.2 & 20 & 26 & 31 & 43 \\
\hline & 17 & \multicolumn{10}{|c|}{ available upon request to site PI } & 16 & 20 & 32 & 45 \\
\hline \multirow{3}{*}{ Alptal $^{\mathrm{f}, \mathrm{g}, \mathrm{h}}$} & 1 & 2.3 & 3.0 & with wood & 6.6 & 0.4 & 19.0 & 25.6 & 19.6 & 12.3 & 45.2 & 39 & 44 & 52 & 50 \\
\hline & 3 & 0.9 & 1.0 & with wood & 3.3 & 1.8 & 20.5 & 22.5 & 7.3 & 6.9 & 29.8 & 30 & 34 & 58 & 59 \\
\hline & 9 & 3.7 & 2.6 & 2.3 & 3.1 & 1.1 & 3.8 & 42.6 & 13.3 & 12.8 & 55.9 & 29 & 19 & 9 & 70 \\
\hline \multirow{3}{*}{$\begin{array}{c}\text { Alptal } \\
\text { Fertilized }^{\mathrm{fg}, \mathrm{g}}\end{array}$} & 2 & 4.6 & 3.0 & 0.8 & $\begin{array}{l}\text { with } \\
\text { organic } \\
\text { soil } \\
\end{array}$ & NA & 5.0 & 55.0 & 21.0 & 8.4 & 76.0 & 36 & 45 & 54 & 51 \\
\hline & 7 & 6.9 & 3.9 & 0.8 & 2.6 & 1.4 & 1.5 & 29.3 & 15.4 & 15.6 & 44.7 & 30 & 37 & 55 & 55 \\
\hline & 14 & 5.0 & 4.4 & 2.0 & 2.7 & 1.2 & 0.9 & 39.6 & 18.9 & 15.3 & 58.5 & 24 & 31 & 53 & 59 \\
\hline Klosterhede $^{\mathrm{i}}$ & 1 & 9.9 & 3.3 & 0.4 & 6.9 & 7.0 & 20.1 & 41.5 & 10.4 & 27.4 & 51.8 & 32 & 47 & 52 & 50 \\
\hline
\end{tabular}




\begin{tabular}{|c|c|c|c|c|c|c|c|c|c|c|c|c|c|c|c|}
\hline & 17 & 12.0 & 4.6 & 1.2 & 3.4 & 2.3 & 0.2 & 61.6 & 3.8 & 23.5 & 65.4 & 11 & 19 & 45 & 70 \\
\hline \multirow{2}{*}{$\begin{array}{l}\text { Klosterhede } \\
\text { Fertilized }^{\mathrm{i}}\end{array}$} & 1 & 16.8 & 6.3 & 0.7 & 11.2 & 10.7 & 3.2 & 23.9 & 22.5 & 45.8 & 46.4 & 38 & 63 & 52 & 34 \\
\hline & 17 & 12.7 & 3.8 & 1.1 & 2.7 & 4.4 & 0.0 & 36.7 & 11.5 & 24.7 & 48.2 & 24 & 25 & 47 & 46 \\
\hline $\begin{array}{c}\text { Bear Brook } \\
\text { Fertilized }^{\mathrm{j}}\end{array}$ & 3 & 2.4 & 9.1 & NA & NA & NA & NA & NA & NA & 11.4 & 23.3 & 40 & 35 & 27 & 37 \\
\hline $\begin{array}{c}\text { Gårdsjön } \\
\text { Fertilized }^{\mathrm{k}}\end{array}$ & 2 & NA & NA & NA & NA & NA & NA & NA & NA & 28.0 & 82.0 & 39 & 47 & 43 & 37 \\
\hline $\begin{array}{c}\text { Aber Low } \\
\text { Fertilization }\end{array}$ & 3 & NA & NA & NA & NA & NA & NA & 17.0 & 15.0 & 32.0 & 32.0 & 49 & 56 & 29 & 33 \\
\hline $\begin{array}{c}\text { Aber High } \\
\text { Fertilization }^{1}\end{array}$ & 3 & NA & NA & NA & NA & NA & NA & 11.0 & 15.0 & 20.0 & 26.0 & 32 & 35 & 21 & 25 \\
\hline
\end{tabular}

*plant recovery from field recoveries excludes ground vegetation.

NA: not available

${ }^{\mathrm{a}}$ Goodale (2017)

bersonal communication with C. Goodale

cNadelhoffer et al. (1999b)

${ }^{\mathrm{d} N a d e l h o f f e r ~ e t ~ a l . ~(2004) ~}$

epersonal communication with $\mathrm{K}$. Nadelhoffer

${ }^{f}$ Krause et al. (2012)

gpersonal communication with P. Schleppi

hProvidoli et al. (2005) and Schleppi et al. (1999)

iGundersen (1998)

${ }^{\mathrm{j} N a d e l h o f f e r ~ e t ~ a l . ~(1999 a) ~}$

${ }^{\mathrm{k}}$ Nadelhoffer et al. (1999c)

'Tietema et al. (1998) 

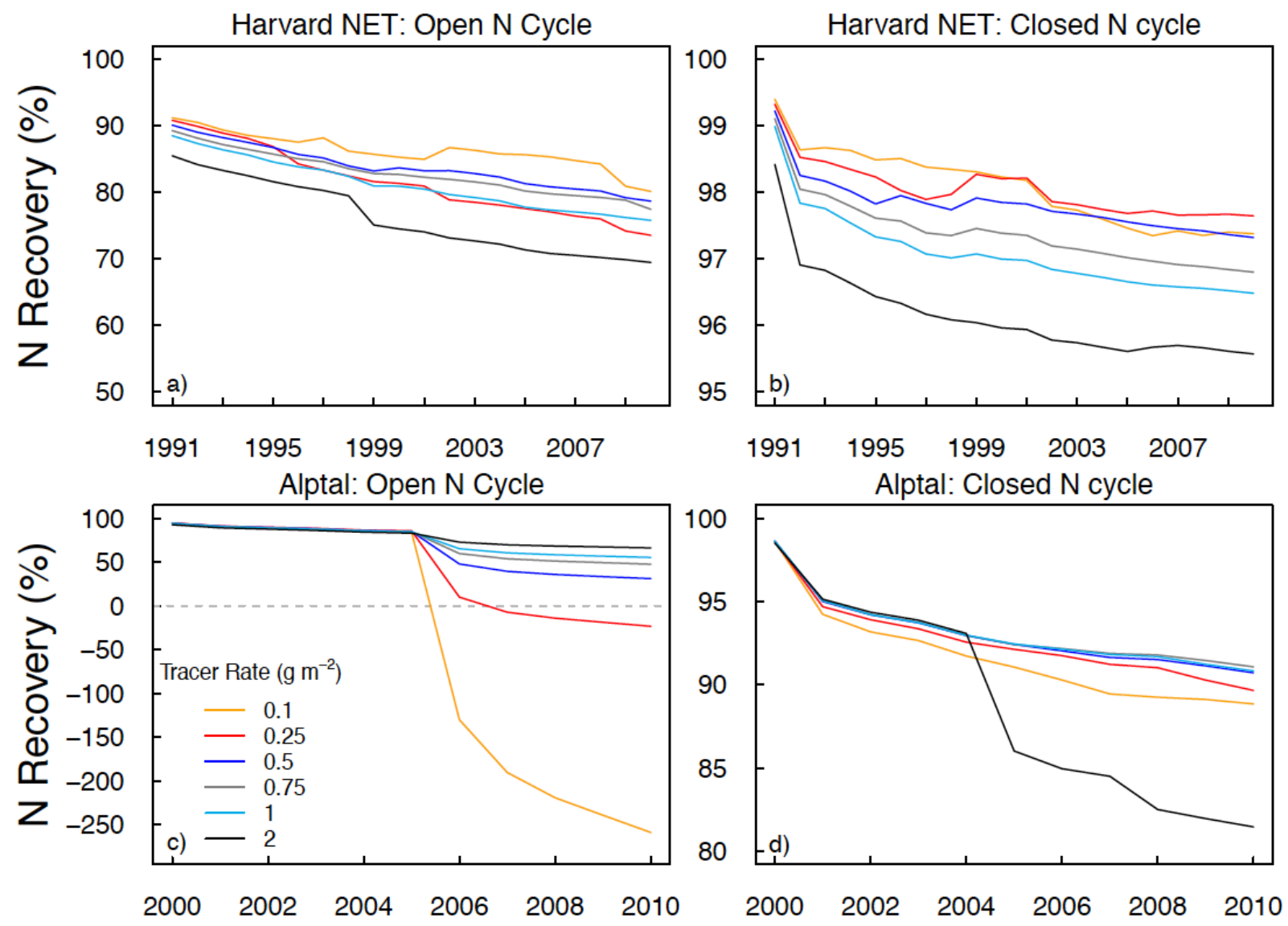

Figure S1: Results from a sensitivity study done at Harvard $(a, b)$ needleleaf temperate tree (NET) plant functional type (PFT) and Alptal (c, d) on the amount of tracer that should be applied during the growing season (April-September) for both open and closed $\mathrm{N}$ cycles in CLM5. 

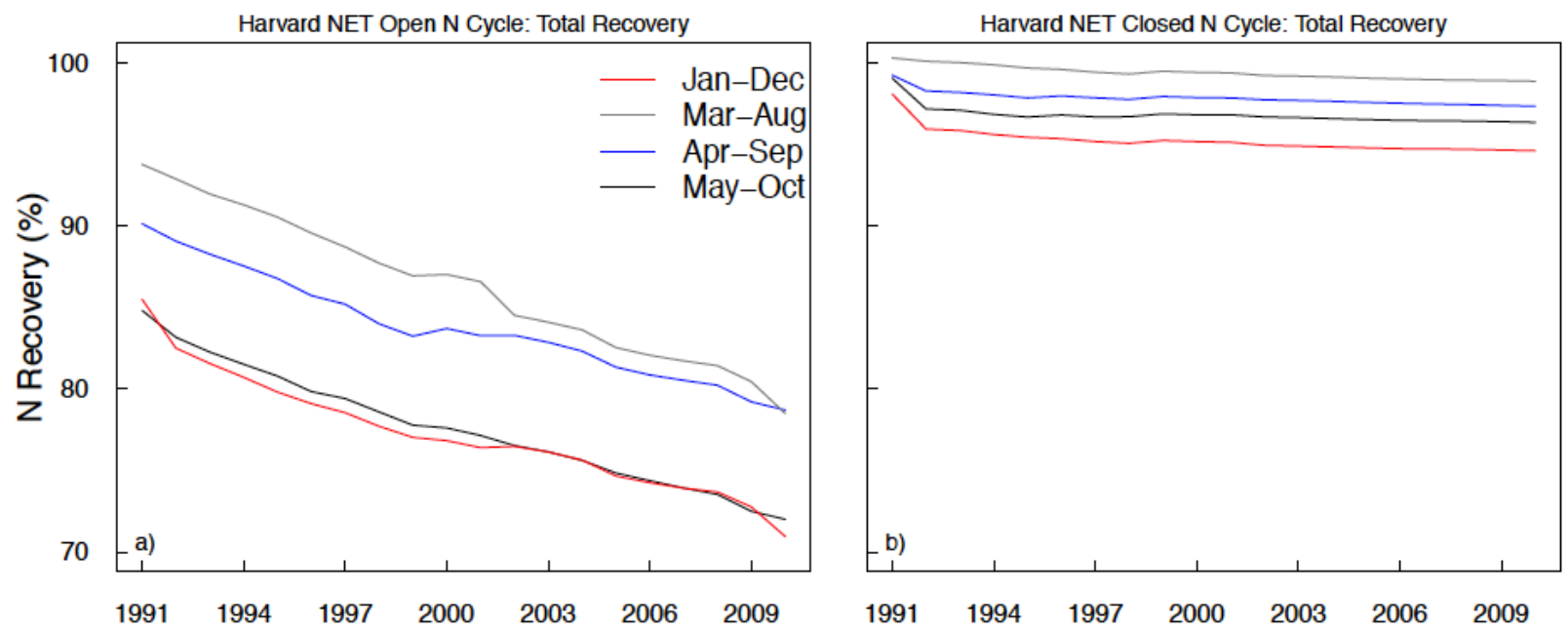

Figure S2: Results from the sensitivity study at Harvard needleleaf evergreen tree (NET) plant functional type (PFT) on the timing of applying $0.5 \mathrm{~g} \mathrm{~N} \mathrm{~m}^{-2}$ into the ecosystem under a) an open $\mathrm{N}$ cycle and b) a closed $\mathrm{N}$ cycle in CLM5. 
Table S2: Turnover time of $\mathrm{N}$ in plant, soil, and total ecosystem pools in CLM5 for ecosystems with open and closed $\mathrm{N}$ cycles. Values shown are averaged across the last 20 years of the 1850 spinup simulation and for the last 20 years of the historical simulation. Turnover time is calculated a) for plants as the plant stock divided by losses from litterfall, b) for soils as the soil stock divided by losses from plant uptake, denitrification, leaching, and runoff, and c) for the ecosystem as the ecosystem stock divided by losses from denitrification, leaching, and runoff.

\begin{tabular}{|c|c|c|c|c|}
\hline & \multicolumn{2}{|c|}{1850} & \multicolumn{2}{|c|}{ Last 20 Years } \\
\hline & $\begin{array}{c}\text { Open N cycle } \\
\text { (years) }\end{array}$ & $\begin{array}{c}\text { Closed N cycle } \\
\text { (years) }\end{array}$ & $\begin{array}{c}\text { Open N cycle } \\
\text { (years) }\end{array}$ & $\begin{array}{c}\text { Closed N cycle } \\
\text { (years) }\end{array}$ \\
\hline \multicolumn{5}{|l|}{ Plants } \\
\hline Harvard BDT & 29 & 30 & 17.6 & 18.0 \\
\hline Harvard NET & 72 & 72 & 53.6 & 56.8 \\
\hline Arnot & 29 & 30 & 23.7 & 24.5 \\
\hline Aber & 72 & 71 & 42.6 & 42.0 \\
\hline Alptal & 73 & 71 & 64.1 & 58.5 \\
\hline Bear Brook & 29 & 30 & 19.4 & 20.5 \\
\hline Klosterhede & 72 & 73 & 58.0 & 55.1 \\
\hline Gårdsjön & 73 & 73 & 58.9 & 59.0 \\
\hline \multicolumn{5}{|l|}{ Soil } \\
\hline Harvard BDT & 93 & 114 & 70 & 95 \\
\hline Harvard NET & 115 & 137 & 100 & 132 \\
\hline Arnot & 143 & 170 & 122 & 158 \\
\hline Aber & 131 & 161 & 95 & 101 \\
\hline Alptal & 184 & 217 & 146 & 152 \\
\hline Bear Brook & 117 & 136 & 93 & 114 \\
\hline Klosterhede & 111 & 130 & 92 & 98 \\
\hline Gårdsjön & 137 & 151 & 111 & 128 \\
\hline \multicolumn{5}{|l|}{ Ecosystem } \\
\hline Harvard BDT & 501 & 7142 & 578 & 6914 \\
\hline Harvard NET & 679 & 5238 & 1597 & 16236 \\
\hline Arnot & 57 & 10606 & 1065 & 12319 \\
\hline Aber & 658 & 3557 & 441 & 1430 \\
\hline Alptal & 2023 & 47976 & 1067 & 3127 \\
\hline Bear Brook & 836 & 7019 & 888 & 6727 \\
\hline Klosterhede & 596 & 6902 & 542 & 2775 \\
\hline Gårdsjön & 1084 & 7787 & 873 & 2903 \\
\hline
\end{tabular}



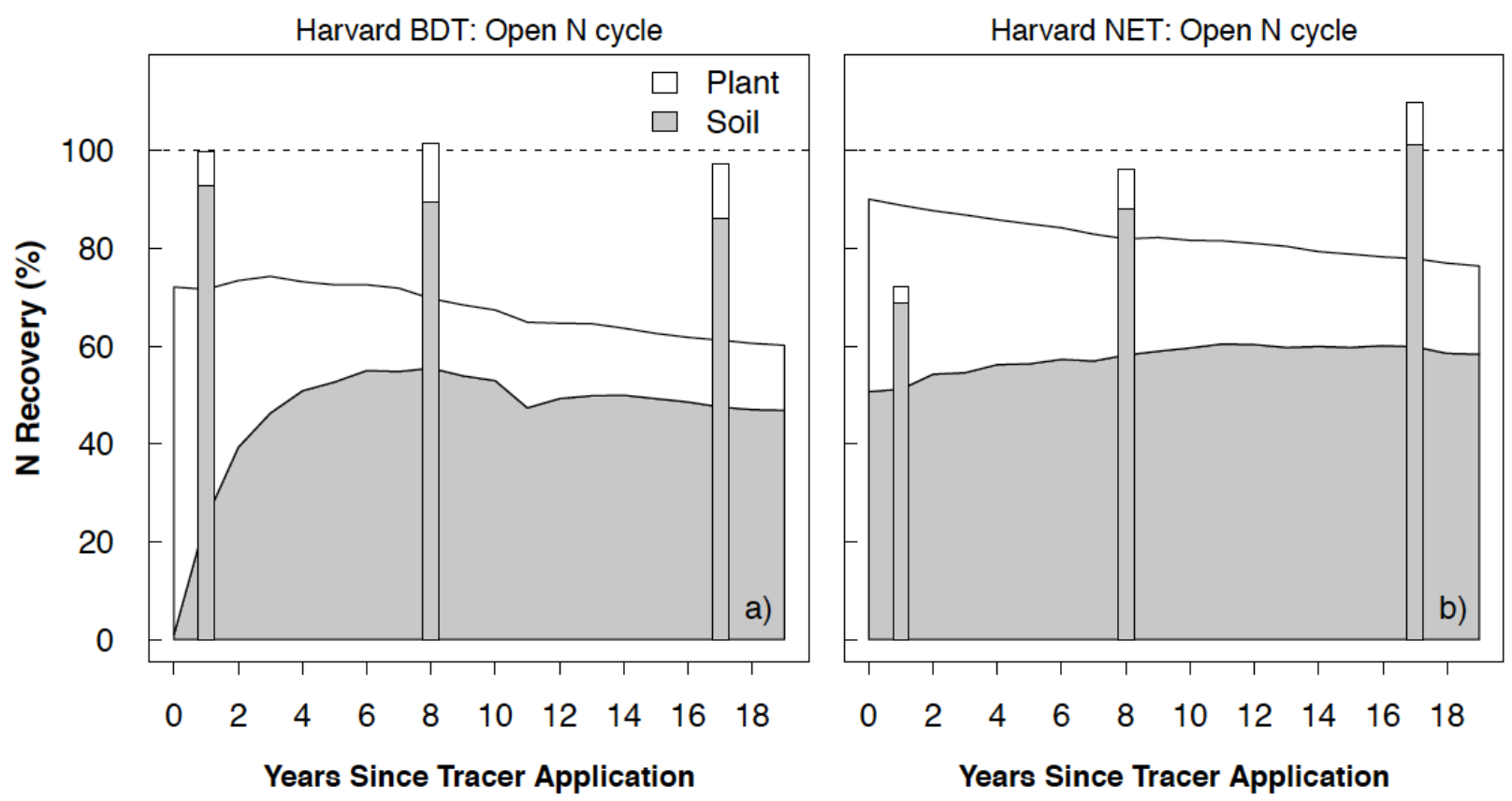

Figure S3: Modeled recovery of $\mathrm{N}$ additions in plant and soil pools at Harvard Forest under open $\mathrm{N}$ cycling and ambient $\mathbf{N}$ deposition for a) broadleaf deciduous tree (BDT) and b) needleleaf evergreen tree (NET) plant functional types (PFT). Thin, stacked bars represent observations. Recovery is calculated as the difference in stock size between a baseline simulation and a simulation with a "tracer" added as $0.5 \mathrm{~g} \mathrm{~m}^{-2}$ between April-September in the first year a ${ }^{15} \mathrm{~N}$ tracer was applied in the field (see Methods). 

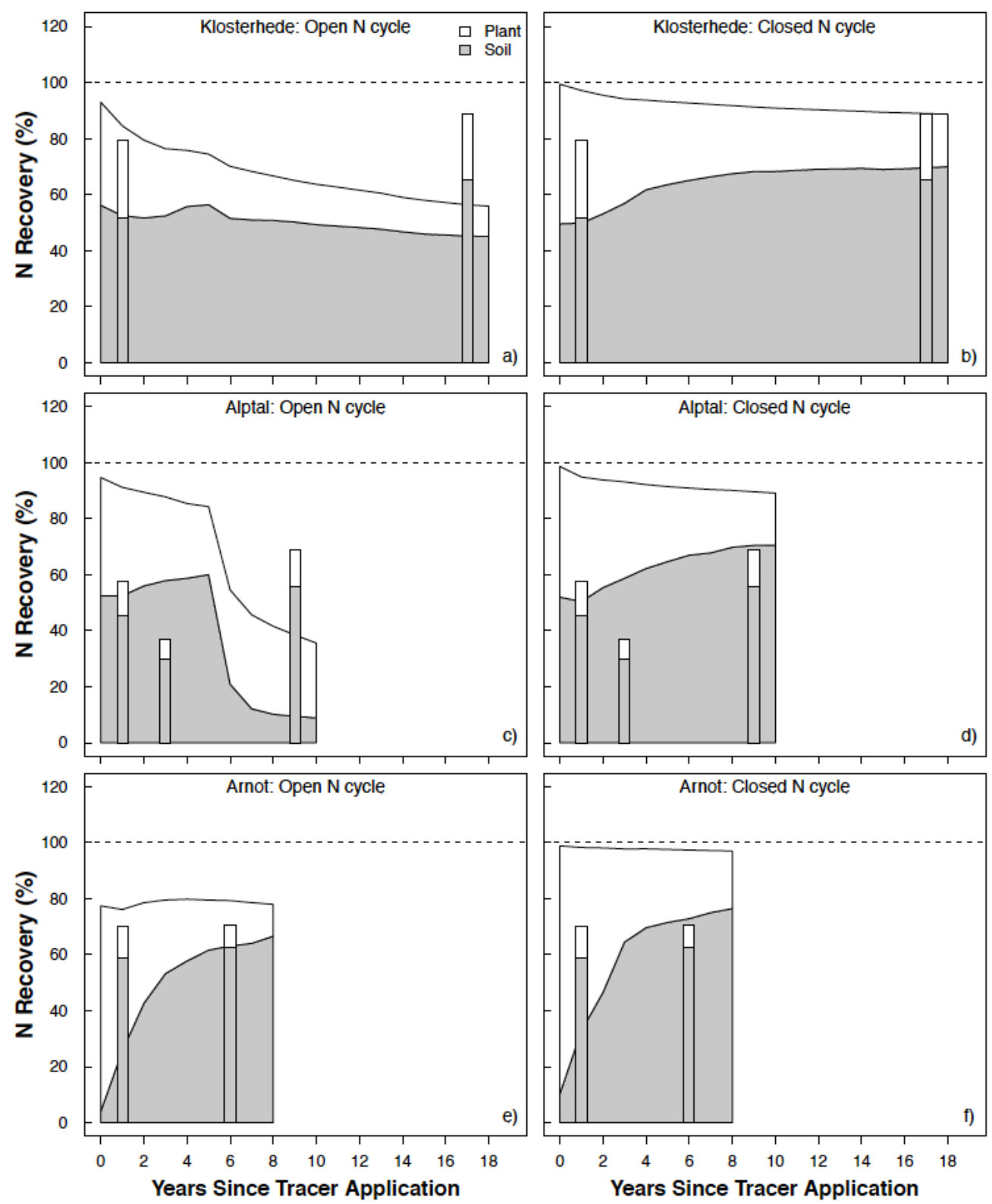

Figure S4: Modeled recovery of $\mathbf{N}$ additions in plant and soil pools in ecosystems with open and closed $\mathbf{N}$ cycles under ambient $\mathrm{N}$ deposition conditions. Thin, stacked bars represent observations. Recovery is calculated as the difference in stock size between a baseline simulation and a simulation with a "tracer" added as $0.5 \mathrm{~g} \mathrm{~m}^{-2}$ between April-September in the first year a ${ }^{15} \mathrm{~N}$ tracer was applied in the field (see Methods). 

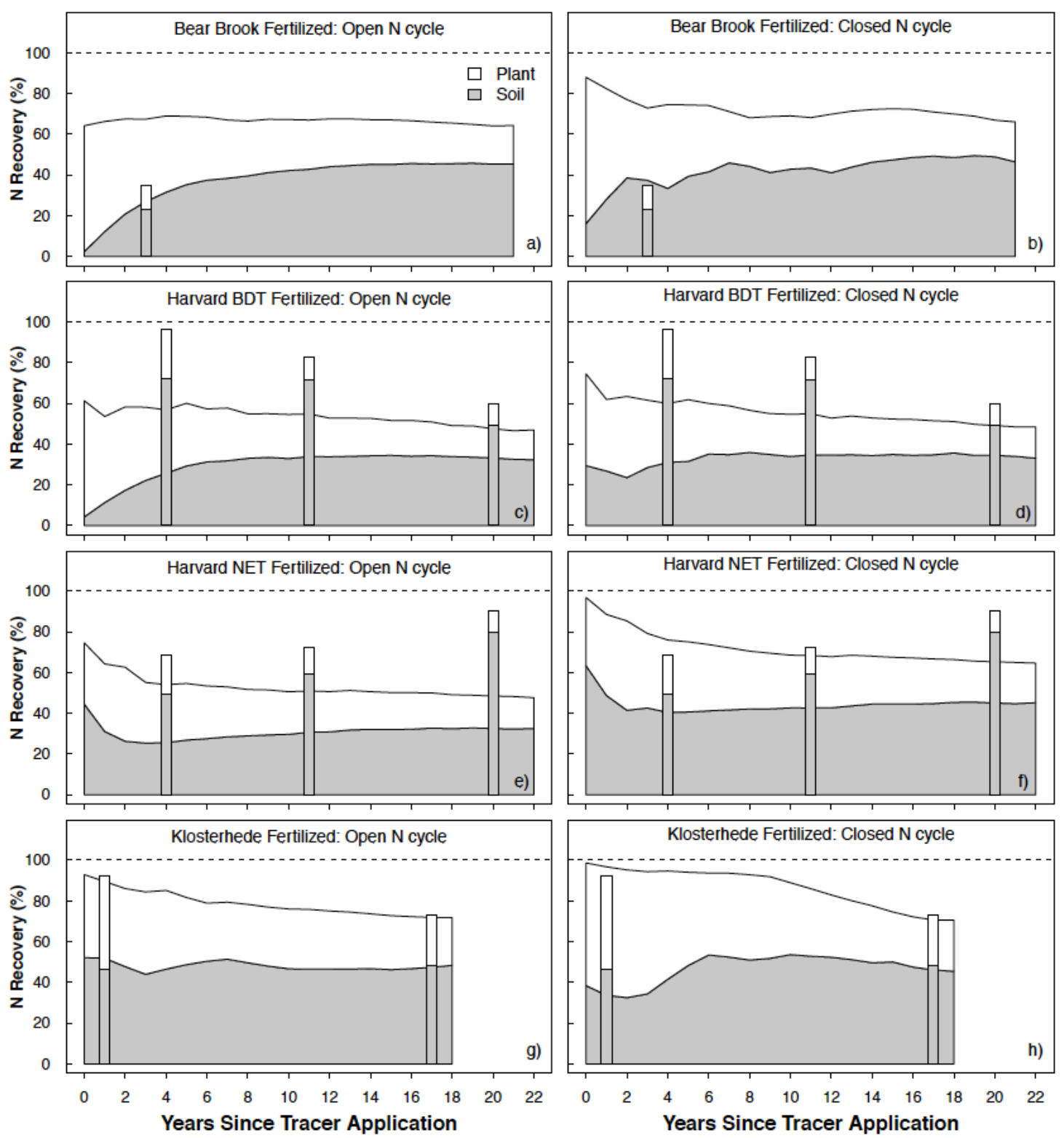

Figure S5: Modeled recovery of $\mathbf{N}$ additions in plant and soil pools of sites in ecosystems with open and closed $\mathbf{N}$ cycles compared to field measurements (thin, stacked bars) for sites under multi-year $\mathbf{N}$ fertilization. Recovery is calculated as the difference in stock size between a baseline simulation and a simulation with $\mathbf{N}$ fertilizer added into the soil mineral $\mathbf{N}$ pool between April-September (see Methods). 

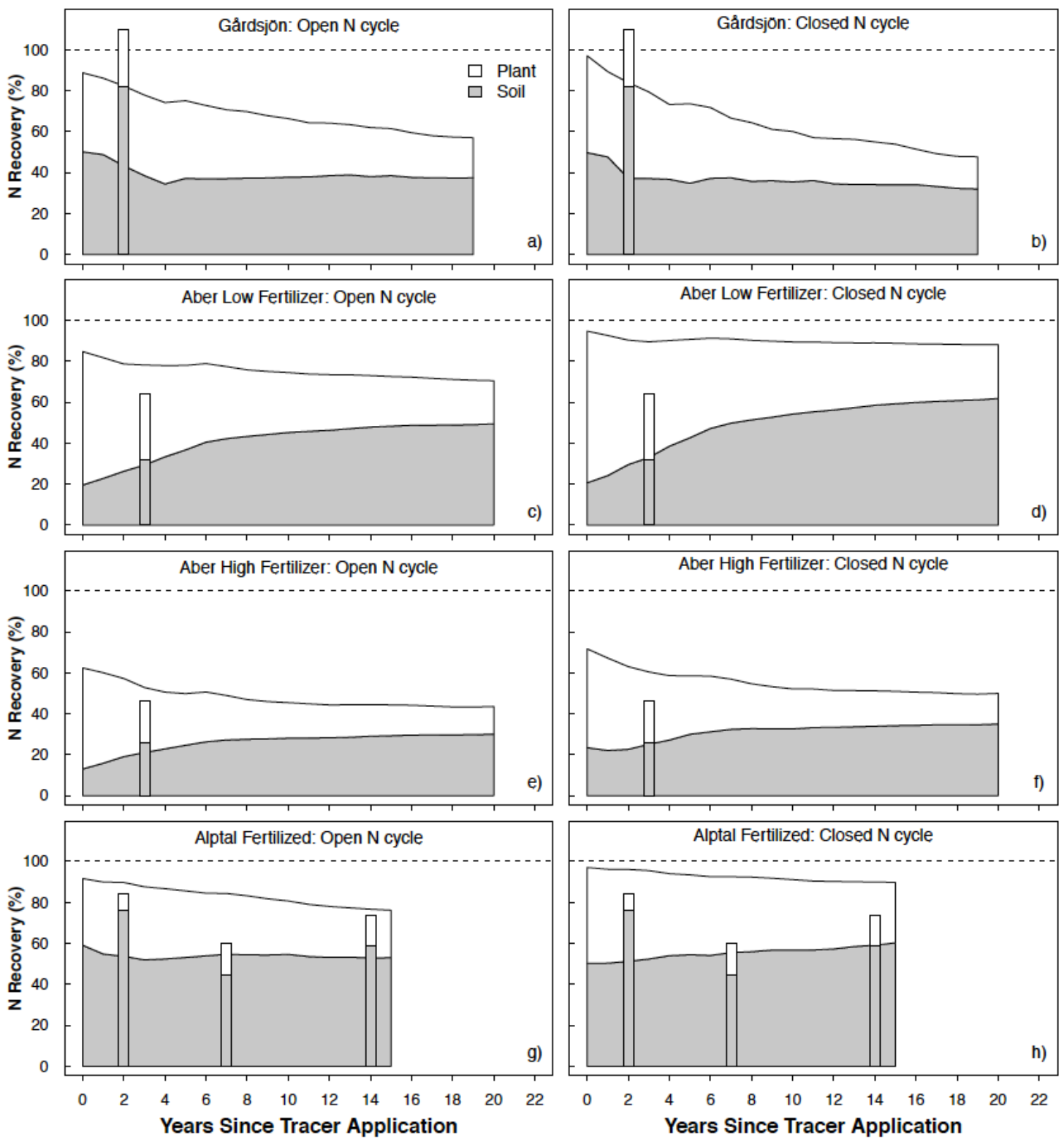

Figure S6: Modeled recovery of $\mathbf{N}$ additions in plant and soil pools of sites for ecosystems under closed and open $\mathbf{N}$ cycles compared to field measurements (thin, stacked bars) for sites under multi-year $\mathbf{N}$ fertilization. Recovery is calculated as the difference in stock size between a control simulation and a simulation with $\mathbf{N}$ fertilizer added into the soil mineral $\mathbf{N}$ pool between April-September (see Methods). 
Table S3: C:N ratios of sub-pools for plants and soils as reported in literature. A .csv file with data from this table is available at https://doi.org/10.5281/zenodo.2772160.

\begin{tabular}{|c|c|c|c|c|c|c|c|c|}
\hline Site & Foliage & Wood & Bark & $\begin{array}{c}\text { Fine } \\
\text { Roots }\end{array}$ & $\begin{array}{l}\text { Coarse } \\
\text { Roots }\end{array}$ & $\begin{array}{l}\text { Organic } \\
\text { Soil }\end{array}$ & $\begin{array}{l}\text { Mineral } \\
\text { Soil }\end{array}$ & Citations \\
\hline Harvard BDT & 25 & 338 & 126 & 50 & NA & 24 & 20 & $\begin{array}{l}\text { Nadelhoffer et al. (1999b); } \\
\text { Nadelhoffer et al. (2004) }\end{array}$ \\
\hline Harvard NET & 42 & 337 & 253 & 41 & NA & 25 & 19 & $\begin{array}{l}\text { Nadelhoffer et al. (1999b); } \\
\text { Nadelhoffer et al. (2004) }\end{array}$ \\
\hline Arnot & 35 & 638 & 154 & 47 & 109 & 39 & 9 & Goodale (2017) \\
\hline Alptal ${ }^{\mathrm{a}}$ & 42 & 500 & 167 & 56 & 91 & 19 & 17 & Providoli et al. (2005) \\
\hline Klosterhedeb & 63 & 333 & 200 & 52 & 70 & 33 & 29 & $\begin{array}{l}\text { Emmett et al. (1998); } \\
\text { Gundersen and Rasmussen } \\
\text { (1995); Tietema et al. (1998); } \\
\text { personal communication with } \\
\text { P. Gundersen }\end{array}$ \\
\hline $\begin{array}{l}\text { Harvard BDT } \\
\text { Fertilized }\end{array}$ & 23 & 321 & 120 & 48 & NA & 21 & 23 & $\begin{array}{l}\text { Nadelhoffer et al. (1999b); } \\
\text { Nadelhoffer et al. (2004) }\end{array}$ \\
\hline $\begin{array}{l}\text { Harvard NET } \\
\text { Fertilized }\end{array}$ & 35 & 409 & 253 & 24 & NA & 23 & 26 & $\begin{array}{l}\text { Nadelhoffer et al. (1999b); } \\
\text { Nadelhoffer et al. (2004) }\end{array}$ \\
\hline $\begin{array}{l}\text { Bear Brook } \\
\text { Fertilized }\end{array}$ & 37 & 413 & NA & NA & NA & 23 & 19 & Nadelhoffer et al. (1999a) \\
\hline Gårdsjön & NA & NA & NA & NA & NA & 32 & 31 & Emmett et al. (1998) \\
\hline Aber ${ }^{b}$ & 28 & NA & NA & NA & NA & 22 & 18 & Emmett et al. (1998) \\
\hline Mean \pm 1 SD & $37 \pm 12$ & $411 \pm 110$ & $182 \pm 55$ & $45 \pm 10$ & $90 \pm 20$ & $26 \pm 6$ & $21 \pm 6$ & \\
\hline
\end{tabular}

NA: not available from literature

${ }^{\mathrm{a}} \mathrm{C}: \mathrm{N}$ ratios of all plant subpools at Alptal were estimated by assuming $50 \%$ of biomass is carbon, and then dividing by the $\mathrm{N}$ concentration reported in the literature.

${ }^{\mathrm{b}} \mathrm{C}: \mathrm{N}$ ratios for foliage at Aber were estimated by assuming $50 \%$ of biomass is carbon, and then dividing by the $\mathrm{N}$ concentration reported in the literature.

\section{References}

Emmett, B. A., Kjønaas, O. J., Gundersen, P., Koopmans, C., Tietema, A., and Sleep, D.: Natural abundance of ${ }^{15} \mathrm{~N}$ in forests across a nitrogen deposition gradient, Forest Ecology and Management, 101, 9-18, https://doi.org/10.1016/S0378-1127(97)00121-7, 1998.

Goodale, C. L.: Multiyear fate of a ${ }^{15} \mathrm{~N}$ tracer in a mixed deciduous forest: retention, redistribution, and differences by mycorrhizal association, Global Change Biology, 23, 867-880, 10.1111/gcb.13483, 2017.

Gundersen, P., and Rasmussen, L.: Nitrogen mobility in a nitrogen limited forest at Klosterhede, Denmark, examined by NH4NO3 addition, Forest Ecology and Management, 71, 75-88, https://doi.org/10.1016/03781127(94)06085-W, 1995.

Gundersen, P.: Effects of enhanced nitrogen deposition in a spruce forest at Klosterhede, Denmark, examined by moderate $\mathrm{NH}_{4} \mathrm{NO}_{3}$ addition, Forest Ecology and Management, 101, 251-268, 10.1016/s03781127(97)00141-2, 1998.

Krause, K., Providoli, I., Currie, W. S., Bugmann, H., and Schleppi, P.: Long-term tracing of whole catchment ${ }^{15} \mathrm{~N}$ additions in a mountain spruce forest: measurements and simulations with the TRACE model, Trees, 26, 1683-1702, 10.1007/s00468-012-0737-0, 2012.

Nadelhoffer, K., Downs, M., Fry, B., Magill, A., and Aber, J.: Controls on N retention and exports in a forested watershed, Environmental Monitoring and Assessment, 55, 187-210, 10.1023/A:1006190222768, 1999a. 
Nadelhoffer, K. J., Downs, M. R., and Fry, B.: Sinks for ${ }^{15} \mathrm{~N}$-enriched additions to an oak forest and a red pine plantation Ecological Applications, 9, 72-86, 10.1890/1051-0761(1999)009[0072:SFNEAT]2.0.CO;2, 1999b.

Nadelhoffer, K. J., Emmett, B. A., Gundersen, P., Kjønaas, O. J., Koopmans, C. J., Schleppi, P., Tietema, A., and Wright, R. F.: Nitrogen deposition makes a minor contribution to carbon sequestration in temperate forests, Nature, 398, 145, 10.1038/18205, 1999c.

Nadelhoffer, K. J., Colman, B. P., Currie, W. S., Magill, A., and Aber, J. D.: Decadal-scale fates of ${ }^{15} \mathrm{~N}$ tracers added to oak and pine stands under ambient and elevated N inputs at the Harvard Forest (USA), Forest Ecology and Management, 196, 89-107, https://doi.org/10.1016/j.foreco.2004.03.014, 2004.

Providoli, I., Bugmann, H., Siegwolf, R., Buchmann, N., and Schleppi, P.: Flow of deposited inorganic N in two gleysol-dominated mountain catchments traced with ${ }^{15} \mathrm{NO}_{3}{ }^{-}$and ${ }^{15} \mathrm{NH}_{4}{ }^{+}$, Biogeochemistry, 76, 453-475, 10.1007/s10533-005-8124-1, 2005.

Schleppi, P., Bucher-Wallin, I., Siegwolf, R., Saurer, M., Muller, N., and Bucher, J. B.: Simulation of Increased Nitrogen Deposition to a Montane Forest Ecosystem: Partitioning of the Added 15N, in: Forest Growth Responses to the Pollution Climate of the 21st Century, edited by: Sheppard, L. J., and Cape, J. N., Springer Netherlands, Dordrecht, 129-134, 1999.

Tietema, A., Emmett, B. A., Gundersen, P., Kjønaas, O. J., and Koopmans, C. J.: The fate of ${ }^{15} \mathrm{~N}$-labelled nitrogen deposition in coniferous forest ecosystems, Forest Ecology and Management, 101, 19-27, https://doi.org/10.1016/S0378-1127(97)00123-0, 1998. 